\title{
OSTEOMIELITE AGUDA DE MANDÍBULA: RELATO DE CASO
}

Cicero BEZERUSKA, Rafaela SCARIOT, Delson COSTA, Nelson REBELATTO, Paulo Roberto MULLER

A osteomielite é uma doença inflamatória, que ocorre nos espaços medulares ou nas superfícies corticais ósseas. Dentre os ossos faciais, a mandíbula é o mais afetado por apresentar um suprimento sanguíneo pobre. 0 tratamento de tal infecção é realizado com altas doses de antibióticos e, freqüentemente, a intervenção cirúrgica também é necessária para promover a curetagem e a remoção de seqüestros ósseos. Paciente F.M.S procurou o Serviço de Cirurgia e Traumatologia Buco-maxilo-faciais da UFPR, com dor em região de parassínfise mandibular do lado esquerdo. Ao exame clínico observou-se aumento de volume e uma coloração gengival esbranquiçada na região dos dentes 35 e 36, e o 35 não respondeu ao teste de vitalidade. Ao exame radiográfico, observou-se área radiolúcida, sem contornos definidos, entremeada por regiões radiopacas associada aos ápices do 35 e 36, com $20 \mathrm{~mm}$ de diâmetro. Sendo assim, optou-se pela remoção cirúrgica dos dentes seguida de curetagem e remoção dos seqüestros ósseos. O paciente foi medicado, com associação de amoxicilina e metronidazol. A peça operatória foi enviada para análise anatomopatológica que confirmou o diagnóstico de osteomielite aguda. Após 01 ano, o paciente encontra-se em controle radiográfico apresentando reparo ósseo e sem sintomatologia de dor e aumento de volume da região.

Palavras-chave: Osteomielite; Mandíbula; Supuração. 